\title{
Sphingomonas rubra sp. nov., isolated from bioreactor wastewater
}

Correspondence
Min Wu
wumin@zju.edu.cn

The genus Sphingomonas was first proposed by Yabuuchi et al. (1990) and the genus description was later emended by Takeuchi et al. (1993, 2001), Yabuuchi et al. (1999, 2002) and Busse et al. (2003). Based on their phylogenetic, chemotaxonomic and phenotypic differences, Takeuchi et al. (2001) divided members of the genus Sphingomonas into four genera: Sphingomonas sensu stricto, Sphingobium, Novosphingobium and Sphingopyxis. Cells of members of the genus Sphingomonas are aerobic, Gram-reactionnegative, chemoheterotrophic, non-motile or motile rods, which form yellow-pigmented colonies, have single polar flagella and are characterized by the presence of sphingolipids, Q-10, 2-hydroxymyristic acid and the absence of

Abbreviation: FAMEs, fatty acid methyl esters.

The GenBank/EMBL/DDBJ accession number for the 16S rRNA gene sequence of strain $\mathrm{BH}^{\top}$ is $\mathrm{FJ} 834325$.

Two supplementary figures and two supplementary tables are available with the online version of this paper. 3-hydroxy fatty acids. Members of the genus Sphingomonas sensu stricto contain $\mathrm{C}_{18: 1}$, saturated $\mathrm{C}_{16: 0}$ and/or $\mathrm{C}_{17: 1}$ as major fatty acids, $\mathrm{C}_{14: 0} 2-\mathrm{OH}$ or $\mathrm{C}_{15: 0} 2-\mathrm{OH}$ as major 2-hydroxy fatty acids and homospermidine as the major polyamine, by which they can be differentiated from members of the genera Sphingobium, Novosphingobium and Sphingopyxis. At the time of writing, the genus Sphingomonas comprised over 60 recognized species. Here we present a polyphasic study describing a novel strain, designated $\mathrm{BH}^{\mathrm{T}}$, of the genus Sphingomonas sensu stricto which was isolated from wastewater in a bioreactor and formed red-pigmented colonies.

Strain $\mathrm{BH}^{\mathrm{T}}$ was isolated from wastewater of a sequential batch reactor treating wastewater from a leather plant. A sample of the wastewater was diluted using a tenfold dilution series method and spread on DSMZ 756 plates. The DSMZ 756 medium contained $\left(1^{-1}\right.$ distilled water): $1.5 \mathrm{~g}$ yeast extract, $1.5 \mathrm{~g}$ peptone, $0.55 \mathrm{~g}$ sodium pyruvate, $1 \mathrm{ml}$ trace element solution, $0.007 \mathrm{~g} \mathrm{CaCO}_{3}, 0.5 \mathrm{~g} \mathrm{NaCl}$, 
$0.05 \mathrm{~g} \mathrm{MgSO}_{4} \cdot 7 \mathrm{H}_{2} \mathrm{O}$ and $0.15 \mathrm{~g} \mathrm{KH}_{2} \mathrm{PO}_{4}$ and was adjusted to $\mathrm{pH} 7.5$ by using $\mathrm{NaOH}$. The trace element solution contained $\left(1^{-1}\right.$ distilled water): $33.8 \mathrm{mg} \mathrm{MnSO}_{4} \cdot \mathrm{H}_{2} \mathrm{O}$, $49.4 \mathrm{mg} \mathrm{H}_{3} \mathrm{BO}_{3}, 43.1 \mathrm{mg} \mathrm{ZnSO} \mathrm{Zn}_{4} \cdot 7 \mathrm{H}_{2} \mathrm{O}, 37.1 \mathrm{mg}\left(\mathrm{NH}_{4}\right)_{6}$ $\mathrm{Mo}_{7} \mathrm{O}_{24}, 97.3 \mathrm{mg} \mathrm{FeSO}_{4} .7 \mathrm{H}_{2} \mathrm{O}$ and $25.0 \mathrm{mg} \mathrm{CuSO}_{4}$. $5 \mathrm{H}_{2} \mathrm{O}$. After 3 days of incubation at $30{ }^{\circ} \mathrm{C}$, a red-coloured colony was picked and a pure culture was obtained by repeated restreaking. The isolate was routinely cultured on DSMZ 756 medium and maintained in a $30 \%(\mathrm{v} / \mathrm{v})$ glycerol suspension at $-80{ }^{\circ} \mathrm{C}$.

Growth in $0,0.5,1,2,3,4,5,6,8,10,12$ and $15 \%(w / v)$ $\mathrm{NaCl}$ was determined in DSMZ 756 medium. Growth at pH 5.0-10.5 (intervals of 0.5) was determined in DSMZ 756 medium using the following buffers (BBI) at a concentration of $40 \mathrm{mM}$ : 2-(N-morpholino)ethanesulfonic acid (MES; pH 5.0-6.0), piperazine- $N, N^{\prime}$-bis(2-ethanesulfonic acid) (PIPES; pH 6.5-7.0), $N$-tris(hydroxymethyl)methylglycine (Tricine; pH 7.5-8.5), 3-(cyclohexylamino)-2-hydroxy-1propanesulfonic acid (CAPSO; pH 9.0-10.0) and 3-(cyclohexylamino)-1-propanesulfonic acid (CAPS; pH 10.5). Growth at 4, 10, 15, 20, 25, 30, 35, 37, 42, 45, 48 and $50{ }^{\circ} \mathrm{C}$ was determined. Cell morphology and motility were examined by optical microscopy (BX40; Olympus) and transmission electron microscopy (JEM-1230; JEOL).

Single carbon source assimilation tests were performed in DSMZ 756 medium without yeast extract, peptone and pyruvate and with a corresponding filter-sterilized sugar $(0.2 \%)$, alcohol $(0.2 \%)$, organic acid $(0.1 \%)$ or amino acid $(0.1 \%)$ added into the liquid medium. Acid production was tested by using oxidation-fermentation (OF) medium supplemented with $1.0 \%$ sugar or alcohol (Hugh \& Leifson, 1953). The OF medium contained $\left(1^{-1}\right.$ distilled water): $2.0 \mathrm{~g}$ casein, $5.0 \mathrm{~g} \mathrm{NaCl}, 0.3 \mathrm{~g} \mathrm{KH}_{2} \mathrm{PO}_{4}$ and $0.08 \mathrm{~g}$ bromothymol blue and was adjusted to $\mathrm{pH} 7.1$ by using $\mathrm{NaOH}$. Physiological and biochemical characteristics of strain $\mathrm{BH} 3^{\mathrm{T}}$ were determined on DSMZ 756 agar using API ZYM, API $20 \mathrm{NE}$ and API $20 \mathrm{E}$ (bioMérieux) tests. API ZYM strips were read after $12 \mathrm{~h}$ and API $20 \mathrm{E}$ and API 20 NE strips after $24 \mathrm{~h}$. Susceptibility to antibiotics was determined on agar plates using discs containing the following antibiotics ( $\mu \mathrm{g}$ per disc unless stated otherwise): amoxicillin (10), ampicillin (10), bacitracin (0.04 IU), carbenicillin (100), cefotaxime (30), cefoxitin (30), chloramphenicol (30), erythromycin (15), gentamicin (10), kanamycin (30), neomycin (30), novobiocin (30), nystatin (100), penicillin (10), rifampicin (5), streptomycin (10), tetracycline (30) and tobramycin (10).

For pigment analysis, pigment was extracted from freezedried cells of strain $\mathrm{BH}^{\mathrm{T}}$ using methanol, according to the methods of Hildebrand et al. (1994), and was scanned by using a Beckman Coulter DU800 spectrophotometer. Fatty acid methyl esters (FAMEs) were obtained from freezedried cells as described by Kuykendall et al. (1988). Identification and quantification of the FAMEs were performed automatically by using the Sherlock Microbial Identification System with the standard MIS Library Generation Software (MIDI). Isoprenoid quinones were analysed as described previously (Komagata \& Suzuki, 1987) using reversed-phase HPLC. Polar lipids were separated on silica gel plates $(10 \times 10 \mathrm{~cm})$ by TLC according to the methods of Xu et al. (2007a) and observed after staining with $10 \%$ ethanolic molybdophosphoric acid. Polyamines were extracted as described by Scherer \& Kneifel (1983) and analysed according to Ducros et al. (2009). Genomic DNA was obtained using the method described by Marmur \& Doty (1962) and the DNA G +C content was determined by reversed-phase HPLC and calculated from the ratio of deoxyguanosine (dG) to deoxythymidine (dT) (Mesbah \& Whitman, 1989).

The 16S rRNA gene of strain $\mathrm{BH}^{\mathrm{T}}$ was amplified and analysed as described previously (Xu et al., 2007b). PCR products were cloned into vector pMD 19-T (TaKaRa) and then sequenced to determine the almost-complete sequence of the 16S rRNA gene, which was compared with sequences of closely related reference organisms obtained from the EzTaxon database (Chun et al., 2007). Sequence data were aligned using CLUSTAL W version 1.8 (Thompson et al., 1994) and phylogenetic trees were constructed by using the neighbour-joining (Saitou \& Nei, 1987) and maximumparsimony (Fitch, 1971) methods in the MEGA 4 program package (Tamura et al., 2007) and the maximum-likelihood method (Felsenstein, 1981) using the RAxML web server (Stamatakis et al., 2008). Distances were calculated for the neighbour-joining method according to the algorithm of the Kimura two-parameter model (Kimura, 1980).

Cells of strain $\mathrm{BH}^{\mathrm{T}}$ were Gram-reaction-negative, rodshaped and $\sim 0.6-1.1 \times 1.1-3.6 \mu \mathrm{m}$ in size. Cells were motile by means of a polar flagellum (Supplementary Fig. S1, available in IJSEM Online). The detailed phenotypic characteristics of strain $\mathrm{BH}^{\mathrm{T}}$ are given in the species description. Differential phenotypic properties of strains $\mathrm{BH}^{\mathrm{T}}$, Sphingomonas melonis DSM $14444^{\mathrm{T}}$ and Sphingomonas aquatilis DSM $15581^{\mathrm{T}}$ are shown in Table 1. Differential characteristics of other closely related species are provided in Supplementary Table S1.

A comparison between the almost-complete 16S rRNA gene sequence $(1448 \mathrm{nt})$ of strain $\mathrm{BH} 3^{\mathrm{T}}$ obtained in this study and those of closely related bacteria indicated that strain $\mathrm{BH}^{\mathrm{T}}$ belonged to the family Sphingomonadaceae. 16S rRNA gene sequence similarities between the novel isolate and members of the genus Sphingomonas sensu stricto ranged from 92.6 to $97.3 \%$, the highest sequence similarities being to $S$. melonis DSM $14444^{\mathrm{T}}(97.3 \%)$ and $S$. aquatilis DSM $15581^{\mathrm{T}}(97.3 \%)$. Sequence similarities between strain $\mathrm{BH}^{\mathrm{T}}$ and other members of the genus Sphingomonas sensu stricto were $<97.0 \%$ and were $<94.6 \%$ when compared with other species of the genus Sphingomonas. Phylogenetic analyses based on 16S rRNA gene sequences showed that strain $\mathrm{BH}^{\mathrm{T}}$ formed a cluster with Sphingomonas aurantiaca and Sphingomonas faeni within the genus Sphingomonas sensu stricto (Fig. 1).

The pigment extracted with methanol from strain $\mathrm{BH}^{\mathrm{T}}$ gave a major peak at $451 \mathrm{~nm}$ and two shoulder peaks at 
Table 1. Differential characteristics of strain $\mathrm{BH}^{\top}$ and closely related strains

Strains: $1, \mathrm{BH} 3^{\mathrm{T}}$; 2. S. melonis DSM $14444^{\mathrm{T}}$; 3. S. aquatilis DSM $15581^{\mathrm{T}}$. Data were obtained from this study under identical growth conditions. +, Positive; -, negative; $\mathrm{W}$, weakly positive; R, red; Y, yellow.

\begin{tabular}{|c|c|c|c|}
\hline Characteristic & 1 & 2 & 3 \\
\hline Colour of colony & $\mathrm{R}$ & $\mathrm{Y}$ & $\mathrm{Y}$ \\
\hline ONPG & - & + & + \\
\hline \multicolumn{4}{|l|}{ Utilization of: } \\
\hline Cellobiose & - & + & + \\
\hline Fumarate & - & + & - \\
\hline L-Glutamate & - & + & + \\
\hline Lactate & - & + & + \\
\hline Rhamnose & - & + & + \\
\hline Sucrose & - & + & + \\
\hline D-Xylose & - & + & + \\
\hline \multicolumn{4}{|l|}{ Utilization of (API $20 \mathrm{NE}$ ): } \\
\hline$N$-Acetylglucosamine & - & + & + \\
\hline Capric acid & - & - & + \\
\hline Phenylacetic acid & - & + & - \\
\hline \multicolumn{4}{|l|}{ Acid production from: } \\
\hline Glucose & - & + & + \\
\hline Rhamnose & - & + & + \\
\hline Sucrose & - & + & + \\
\hline Maltose & - & + & + \\
\hline D-Xylose & - & + & + \\
\hline \multicolumn{4}{|l|}{ Sensitivity to: } \\
\hline Amoxicillin & + & - & - \\
\hline Cefotaxime & + & - & - \\
\hline Cefoxitin & + & - & - \\
\hline \multicolumn{4}{|l|}{ Enzyme activities (API ZYM) } \\
\hline$\alpha$-Chymotrypsin & + & - & - \\
\hline$\beta$-Galactosidase & - & + & + \\
\hline$\beta$-Glucuronidase & - & + & - \\
\hline$N$-Acetyl- $\beta$-glucosaminidase & - & + & + \\
\hline \multicolumn{4}{|c|}{ Fermentation/oxidation of (API $20 \mathrm{E}$ ): } \\
\hline Amygdalin & - & + & + \\
\hline L-Arabinose & - & + & + \\
\hline D-Glucose & - & $\mathrm{w}$ & $\mathrm{w}$ \\
\hline L-Rhamnose & - & $\mathrm{w}$ & $\mathrm{w}$ \\
\hline Sucrose & - & + & + \\
\hline
\end{tabular}

423 and $475 \mathrm{~nm}$, typical of carotenoids, whereas the major peaks of the most closely related species were at $448 \mathrm{~nm}$ for S. melonis DSM $14444^{\mathrm{T}}$ and $447 \mathrm{~nm}$ for S. aquatilis DSM $15581^{\mathrm{T}}$. To further verify that strain $\mathrm{BH}^{\mathrm{T}}$ was a novel species of the genus Sphingomonas, DNA-DNA hybridizations were performed using the thermal denaturation and renaturation method of De Ley et al. (1970) with modifications (Huß et al., 1983), using a Beckman DU 800 spectrophotometer. The hybridization temperature used was $78{ }^{\circ} \mathrm{C}$ and the experiments were carried out in triplicate. DNA-DNA relatedness values of $42 \%$ and $33 \%$ between strain $\mathrm{BH}^{\mathrm{T}}$ and reference strains S. melonis DSM $14444^{\mathrm{T}}$ and S. aquatilis DSM $15581^{\mathrm{T}}$, respectively, were significantly lower than $70 \%$, the recommended threshold value for the delineation of bacterial species (Wayne et al., 1987). Strain $\mathrm{BH} 3^{\mathrm{T}}$ had chemotaxonomic characteristics typical of members of the genus Sphingomonas, such as the presence of sphingoglycolipids (see Supplementary Fig. S2), Q-10, 2-hydroxymyristic acids and the absence of 3-hydroxy fatty acids (Busse et al., 1999). The presence of $\mathrm{C}_{18: 1} \omega 7 c(39.2 \%)$ and $\mathrm{C}_{16: 0}(11.2 \%)$ as major fatty acids, $\mathrm{C}_{14: 0}$ 2-OH $(20.6 \%)$ as the major 2-hydroxy fatty acid and homospermidine as the major polyamine also indicated that strain $\mathrm{BH} 3^{\mathrm{T}}$ belonged to the genus Sphingomonas sensu stricto (Takeuchi et al., 2001). However, the proportion of $\mathrm{C}_{18: 1} \omega 7 c$ of strain $\mathrm{BH}^{\mathrm{T}}$ was lower than that of $S$. melonis DSM $14444^{\mathrm{T}}(61.2 \%)$, S. aquatilis DSM $15581^{\mathrm{T}}(56.1 \%)$, S. pruni $(73.1 \%)$ and S. mali $(70.5 \%)$ and the proportion of iso- $\mathrm{C}_{15: 0}$ 2-OH and/or $\mathrm{C}_{16: 1} \omega 7 c$ of strain $\mathrm{BH}^{\mathrm{T}}$ $(18.9 \%)$ was higher than that of S. melonis DSM $14444^{\mathrm{T}}$ $(5.0 \%)$ and S. aquatilis DSM $15581^{\mathrm{T}}$ (4.9\%). Compared with S. melonis DSM $14444^{\mathrm{T}}$ and S. aquatilis DSM $15581^{\mathrm{T}}$, strain $\mathrm{BH}^{\mathrm{T}}$ also contained a small amount of 10-methyl $\mathrm{C}_{19: 0}$ and $\mathrm{C}_{15: 1} \omega 6 c$ but no $\mathrm{C}_{18: 1} \omega 5 c$ or $\mathrm{C}_{18: 1} 2-\mathrm{OH}$ was detected (Supplementary Table S2).

The comparison of phenotypic properties between strain $\mathrm{BH} 3^{\mathrm{T}}$ and S. melonis DSM $14444^{\mathrm{T}}$ and S. aquatilis DSM $15581^{\mathrm{T}}$ also indicated differences in colony colour, the utilization of carbon sources, acid production from sugars and several enzyme activities (Table 1).

On the basis of the phylogenetic, genotypic, chemotaxonomic and phenotypic data, strain $\mathrm{BH} 3^{\mathrm{T}}$ represents a novel species of the genus Sphingomonas sensu stricto, for which the name Sphingomonas rubra sp. nov. is proposed.

\section{Description of Sphingomonas rubra sp. nov.}

Sphingomonas rubra (ru'bra. L. fem. adj. rubra red).

Cells are Gram-reaction-negative, rod-shaped, 0.6-1.1× 1.1-3.6 $\mu \mathrm{m}$ and motile. Colonies are 1-2 $\mathrm{mm}$ in diameter, circular, elevated and red when grown on DSMZ 756 medium for 2 days at $28{ }^{\circ} \mathrm{C}$. Growth occurs in $0-8 \%(\mathrm{w} / \mathrm{v})$ $\mathrm{NaCl}$ (optimum $0 \%$ ), at pH 6-9 (optimum pH 7.5) and at 4-37 ${ }^{\circ} \mathrm{C}$ (optimum $28{ }^{\circ} \mathrm{C}$ ). Oxidase- and catalase-positive. Aesculin is hydrolysed. Casein, DNA, gelatin, starch, Tweens 20 and 80 and tyrosine are not hydrolysed. Negative for indole production and arginine dihydrolase, lysine carboxylase, ornithine carboxylase, tryptophan deaminase, urease and $o$-nitrophenyl- $\beta$-D-galactopyranosidase activities. Hydrogen sulfide is not produced. L-Cysteine, $\mathrm{D}$-galactose and L-valine are utilized and glucose and maltose are weakly utilized. The following compounds are not utilized as sole carbon sources: acetate, L-arginine, L-aspartate, cellobiose, citrate, ethanol, formate, fumarate, gluconate, L-glutamate, glycine, glycerol, L-histidine, myo-inositol, isoleucine, lactate, malonate, mannitol, L-methionine, L-ornithine, propionate, pyruvate, raffinose, D-ribose, rhamnose, L-serine, D-sorbitol, L-sorbose, sucrose, starch and $\mathrm{D}$-xylose. Acid is produced from L-arabinose but not from adonitol, ethanol, D-fructose, glucose, glycerol, myo-inositol, 


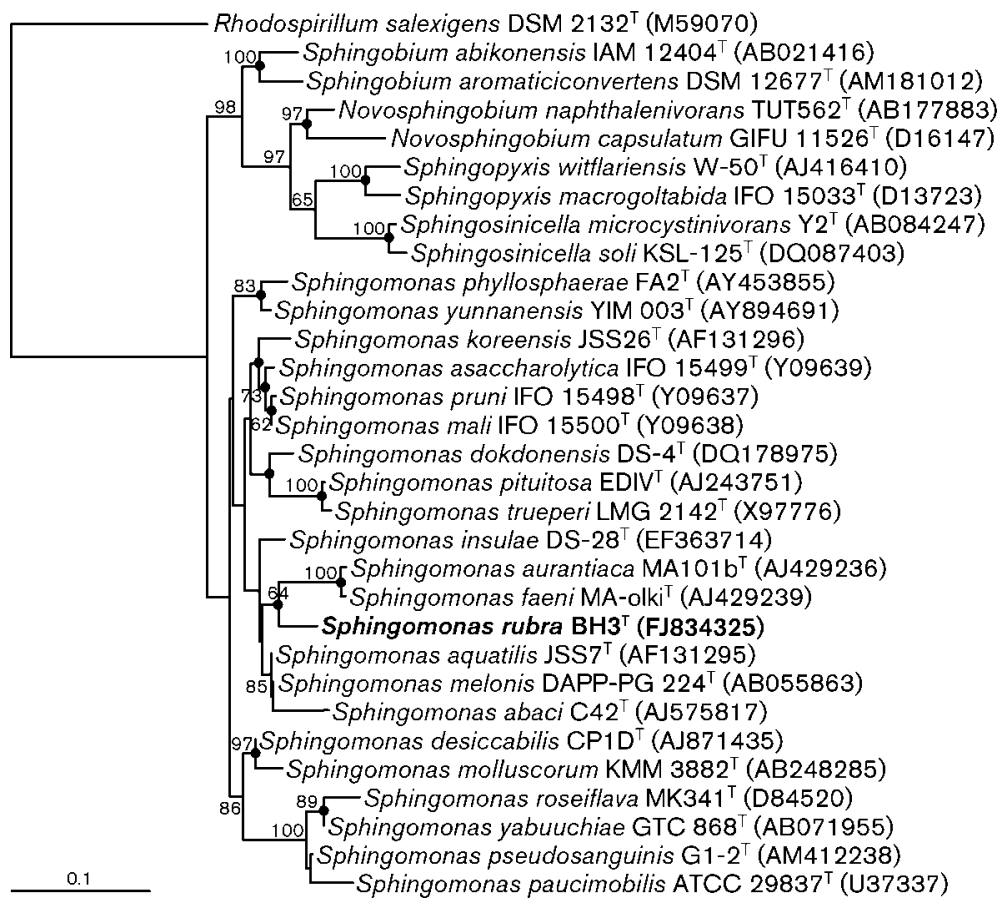

Fig. 1. Maximum-likelihood tree based on $16 \mathrm{~S}$ rRNA gene sequences showing the phylogenetic relationships between strain $\mathrm{BH}^{\top}$ and related taxa. Bootstrap values $>50 \%$ (based on 100 replicates) are given at branch points. Rhodospirillum salexigens DSM $2132^{\top}$ was used as an outgroup. Bar, 0.1 substitutions per nucleotide position. Filled circles indicate nodes also recovered in the neighbour-joining and maximum-parsimony trees.

maltose, mannitol, raffinose, rhamnose, D-salicin, D-sorbitol, L-sorbose, sucrose, trehalose or D-xylose. In the API ZYM system, acid phosphatase, alkaline phosphatase, $\alpha$-chymotrypsin, esterase (C4), esterase lipase (C8), $\alpha$-glucosidase, leucine arylamidase, naphthol-AS-BI-phosphohydrolase and valine arylamidase activities are present, whereas $N$-acetyl- $\beta$ glucosaminidase, $\beta$-fucosidase, $\alpha$ - and $\beta$-galactosidase, $\beta$-glucuronidase, lipase (C14), $\alpha$-mannosidase and trypsin activities are absent. Susceptible to ( $\mu \mathrm{g}$ unless otherwise stated) amoxicillin (10), cefataxime (30), cefoxitin (30), chloramphenicol (30), erythromycin (15), gentamicin (10), kanamycin (30), neomycin (30), novobiocin (30), rifampicin (5), tetracycline (30) and tobramycin (10) but not to ampicillin (10), bacitracin (0.04 IU), carbenicillin (100), nystatin (100), penicillin (10) or streptomycin (10). The predominant quinone is $\mathrm{Q}-10$. The major polyamine is homospermidine. The major polar lipids of strain $\mathrm{BH} 3^{\mathrm{T}}$ are phosphatidylethanolamine, phosphatidylglycerol, phosphatidyldimethylethanolamine and diphosphatidylglycerol as well as two sphingoglycolipids and an unidentified lipid. Small amounts of two unidentified lipids are also present. The major fatty acids $(>5 \%)$ include $\mathrm{C}_{18: 1} \omega 7 c, \mathrm{C}_{14: 0} 2-\mathrm{OH}$, iso- $\mathrm{C}_{15: 0} 2-\mathrm{OH}$ and/or $\mathrm{C}_{16: 1} \omega 7 c$ and $\mathrm{C}_{16: 0}$.

The type strain, $\mathrm{BH}^{\mathrm{T}}\left(=\mathrm{CGMCC} 1.9113^{\mathrm{T}}=\mathrm{JCM} 16230^{\mathrm{T}}\right)$, was isolated from wastewater of a sequential batch reactor treating wastewater taken from a leather plant. The DNA $\mathrm{G}+\mathrm{C}$ content of the type strain is $65.6 \mathrm{~mol} \%$.

\section{Acknowledgements}

This work was supported by grants from the Ministry of Science and Technology of China (863 Program, 2007AA021305), the National
Natural Science Foundation of China (30970002; 40806066), the Zhejiang Provincial Natural Science Foundation of China (Y5080060) and the Key Project of Zhejiang Science and Technology (2006C13053).

\section{References}

Busse, H.-J., Kämpfer, P. \& Denner, E. B. M. (1999). Chemotaxonomic characterisation of Sphingomonas. J Ind Microbiol Biotechnol 23, 242-251.

Busse, H.-J., Denner, E. B. M., Buczolits, S., Salkinoja-Salonen, M., Bennasar, A. \& Kämpfer, P. (2003). Sphingomonas aurantiaca sp. nov., Sphingomonas aerolata sp. nov. and Sphingomonas faeni sp. nov., air- and dustborne and Antarctic, orange-pigmented, psychrotolerant bacteria, and emended description of the genus Sphingomonas. Int $J$ Syst Evol Microbiol 53, 1253-1260.

Chun, J., Lee, J.-H., Jung, Y., Kim, M., Kim, S., Kim, B. K. \& Lim, Y.-W. (2007). EzTaxon: a web-based tool for the identification of prokaryotes based on $16 \mathrm{~S}$ ribosomal RNA gene sequences. Int J Syst Evol Microbiol 57, 2259-2261.

De Ley, J., Cattoir, H. \& Reynaerts, A. (1970). The quantitative measurement of DNA hybridization from renaturation rates. Eur $J$ Biochem 12, 133-142.

Ducros, V., Ruffieux, D., Belva-Besnet, H., de Fraipont, F., Berger, F. \& Favier, A. (2009). Determination of dansylated polyamines in red blood cells by liquid chromatography-tandem mass spectrometry. Anal Biochem 390, 46-51.

Felsenstein, J. (1981). Evolutionary trees from DNA sequences: a maximum likelihood approach. J Mol Evol 17, 368-376.

Fitch, W. M. (1971). Toward defining the course of evolution: minimum change for a specific tree topology. Syst Zool 20, 406-416.

Hildebrand, D. C., Palleroni, N. J., Hendson, M., Toth, J. \& Johnson, J. L. (1994). Pseudomonas flavescens sp. nov., isolated from walnut blight cankers. Int J Syst Bacteriol 44, 410-415. 
Hugh, R. \& Leifson, E. (1953). The taxonomic significance of fermentative versus oxidative metabolism of carbohydrates by various Gram negative bacteria. J Bacteriol 66, 24-26.

Huß, V. A. R., Festl, H. \& Schleifer, K. H. (1983). Studies on the spectrophotometric determination of DNA hybridization from renaturation rates. Syst Appl Microbiol 4, 184-192.

Kimura, M. (1980). A simple method for estimating evolutionary rates of base substitutions through comparative studies of nucleotide sequences. J Mol Evol 16, 111-120.

Komagata, K. \& Suzuki, K.-I. (1987). Lipids and cell-wall analysis in bacterial systematics. Methods Microbiol 19, 161-207.

Kuykendall, L. D., Roy, M. A., O’Neill, J. J. \& Devine, T. E. (1988). Fatty acids, antibiotic resistance, and deoxyribonucleic acid homology groups of Bradyrhizobium japonicum. Int J Syst Bacteriol 38, 358-361.

Marmur, J. \& Doty, P. (1962). Determination of the base composition of deoxyribonucleic acid from its thermal denaturation temperature. J Mol Biol 5, 109-118.

Mesbah, M. \& Whitman, W. B. (1989). Measurement of deoxyguanosine/thymidine ratios in complex mixtures by high-performance liquid chromatography for determination of the mole percentage guanine + cytosine of DNA. J Chromatogr A 479, 297-306.

Saitou, N. \& Nei, M. (1987). The neighbor-joining method: a new method for reconstructing phylogenetic trees. Mol Biol Evol 4, 406-425.

Scherer, P. \& Kneifel, H. (1983). Distribution of polyamines in methanogenic bacteria. J Bacteriol 154, 1315-1322.

Stamatakis, A., Hoover, P. \& Rougemont, J. A. (2008). A rapid bootstrap algorithm for the RAXML Web servers. Syst Biol 57, 758-771.

Takeuchi, M., Kawai, F., Shimada, Y. \& Yokota, A. (1993). Taxonomic study of polyethylene glycerol-utilizing bacteria: emended description of the genus Sphingomonas and new descriptions of Sphingomonas macrogoltabidus sp. nov., Sphingomonas sanguis sp. nov. and Sphingomonas terrae sp. nov. Syst Appl Microbiol 16, 227-238.

Takeuchi, M., Hamana, K. \& Hiraishi, A. (2001). Proposal of the genus Sphingomonas sensu stricto and three new genera, Sphingobium, Novosphingobium and Sphingopyxis, on the basis of phylogenetic and chemotaxonomic analyses. Int J Syst Evol Microbiol 51, 1405-1417.
Tamura, K., Dudley, J., Nei, M. \& Kumar, S. (2007). MEGA4: molecular evolutionary genetics analysis (MEGA) software version 4.0. Mol Biol Evol 24, 1596-1599.

Thompson, J. D., Higgins, D. G. \& Gibson, T. J. (1994). CLUSTAL W: improving the sensitivity of progressive multiple sequence alignment through sequence weighting, position-specific gap penalties and weight matrix choice. Nucleic Acids Res 22, 4673-4680.

Wayne, L. G., Brenner, D. J., Colwell, R. R., Grimont, P. A. D., Kandler, O., Krichevsky, M. I., Moore, L. H., Moore, W. E. C., Murray, R. G. E. \& other authors (1987). International Committee on Systematic Bacteriology. Report of the ad hoc committee on reconciliation of approaches to bacterial systematics. Int J Syst Bacteriol 37, 463-464.

Xu, X.-W., Wu, Y.-H., Wang, C.-S., Oren, A., Zhou, P.-J. \& Wu, M. (2007a). Haloferax larsenii sp. nov., an extremely halophilic archaeon from a solar saltern. Int J Syst Evol Microbiol 57, 717-720.

Xu, X.-W., Wu, Y.-H., Zhou, Z., Wang, C.-S., Zhou, Y.-G., Zhang, H.-B., Wang, Y. \& Wu, M. (2007b). Halomonas saccharevitans sp. nov., Halomonas arcis sp. nov. and Halomonas subterranea sp. nov., halophilic bacteria isolated from hypersaline environments of China. Int J Syst Evol Microbiol 57, 1619-1624.

Yabuuchi, E., Yano, I., Oyaizu, H., Hashimoto, Y., Ezaki, T. \& Yamamoto, H. (1990). Proposals of Sphingomonas paucimobilis gen. nov. and comb. nov., Sphingomonas parapaucimobilis sp. nov., Sphingomonas yanoikuyae sp. nov., Sphingomonas adhaesiva sp. nov., Sphingomonas capsulata comb. nov., and two genospecies of the genus Sphingomonas. Microbiol Immunol 34, 99-119.

Yabuuchi, E., Kosako, Y., Naka, T., Suzuki, S. \& Yano, I. (1999). Proposal of Sphingomonas suberifaciens (van Bruggen, Jochimsen and Brown 1990) comb. nov., Sphingomonas natatoria (Sly 1985) comb. nov., Sphingomonas ursincola (Yurkov et al. 1997) comb. nov., and emendation of the genus Sphingomonas. Microbiol Immunol 43, 339349.

Yabuuchi, E., Kosako, Y., Fujiwara, N., Naka, T., Matsunaga, I., Ogura, H. \& Kobayashi, K. (2002). Emendation of the genus Sphingomonas Yabuuchi et al. 1990 and junior objective synonymy of the species of three genera, Sphingobium, Novosphingobium and Sphingopyxis, in conjunction with Blastomonas ursincola. Int J Syst Evol Microbiol 52, 1485-1496. 